\title{
Epiphytic bet-mannanase producing bacterial strains
}

\author{
Ekaterina Epova $^{2}$, Svetlana Petrova ${ }^{2}$,Elena Trubnikova ${ }^{3}$, Maria Danilova ${ }^{4}$ \\ ${ }^{1}$ Emanuel institute of biochemical physics, Russian Academy of Sciences, Kosygin st. 4, Moscow, 119334, Russia \\ ${ }^{2}$ Ivanov Agricultural State Academy, Karl Marx st. 70, Kursk, 305021, Russia \\ ${ }^{3}$ Kursk State University, Radishev st. 3, Kursk, 305000, Russia \\ ${ }^{4}$ Vavilov Institute of General Genetics, Russian Academy of Sciences, Gubkin st. 3,Moscow, 119333, Russia
}

\begin{abstract}
Dry remains of the herbal species of the plantain (Plantago major), the wormwood (Artemisia vulgaris) and the reed grass (Calamagrostis acutiflora) were used as a natural source for isolation of $\beta$ mannanase producing strains. They were isolated by using the carob gum as a single source of carbon and energy. Each chosen plant species was found to be colonized with a single dominant epiphytic group of microorganism, although the plants had been collected in the same location. Bacillus circulans was only found in P. major, Bacillus subtilis on A. vulgaris, whereas Pantoea sp. was found in C. acutiflora. Identification of the taxonomy affiliation of the isolated $\beta$-mannanase producers allowed using the formerly proposed primers for PCR cloning of $\beta$-mannanase genes previously occurred in the respective bacterial species. This approach let us cloning $330 \mathrm{bp}$ fragment of $\beta$-mannanase genes from $B$. circulans and $B$. subtilis and $1000 \mathrm{bp}$ fragment of $\beta$-mannanase gene from Pantoea sp. Testing the enzymatic activity of the isolated strains by staining the carob gum hydrolysis zones on the plates with Congo Red was carried out. As a result, the maximum activity was found in Pantoea sp.
\end{abstract}

\section{Introduction}

$\beta$-Mannanases are currently considered as the most promising type of the feed enzymes. However, they are not still readily available as commercial products and the physiological value of the reported prototypes has not been sufficiently characterized [1]. The substrate of $\beta$ mannanases is $1,4-\beta-$ mannan, which is found in grains in proportion ranging from 0.5 to $2 \%$ of the total dry weight [2]. Average share of $\beta$-mannan in the wheat, rye and barley grain is $\sim 0.2 \%$ of the dry weight; the corn, triticale and bran contain $\sim 0.6 \%$; soybean meal and oilcake of different cultures contain 1.6-2.5\% $\beta$-mannan.

A relevant approach to using $\beta$-mannanases in the feeding is establishing feed additives with immunomodulatory properties for piglets and other farm animals [3, 4]. Analyzing the reasons for the well documented high efficiency of $\beta$-mannanases in premixes leads to the conclusion that it is related with modulation of the water-retention ability is $1,4-\beta-\mathrm{D}$ mannan. The water-retention ability of free $1,4-\beta-\mathrm{D}-$ mannan 10-folds or more exceeded one in the denatured starch and other well characterized polysaccharides [5]. First, partial enzymatic hydrolysis sharply increases water retention ability of $\beta$-mannan in the seed shells of the grain (it attains a value of 1:40 - 1:110), and then rapidly drops up to a negligible value. The swelling of $\beta$ mannan in the intestine hinders the motility of the chime and absorption of nutrients, which substantially decreases the daily weight gain. That is why $\beta$-mannan plays a significant role in the apparent feed efficiency of the grain not proportional to its relatively low content in the diet. Obviously, the mechanism of action of the $\beta$-mannanases on the feed components (first of all, the grain), requires an in-depth studies that can lead to a revolutionary improvement in the feed efficiency of the existing raw materials for animal husbandry.

$\beta$-Mannanases are commercially available for manufacturing premixes mostly as complex feed preparations containing enzyme blends. Examples are Sunzyme (Wuhan Sunhy Biology Co., Ltd, China) fungal preparation containing nutrients $\sim 200 \mathrm{U} / \mathrm{g}$. CTC ZYME (CTC Bio, Southern Korea) is a recombinant enzyme from B. lentus with activity $800 \mathrm{U} / \mathrm{g}$. AveMix XG 10 and AveMix ®02 CS (AVEVE Biochem NV, Belgium/China) are enzyme blends derived from Trichoderma spp. and Aspergillus spp. with a specific activity $80 \mathrm{U} / \mathrm{g}$ and $120 \mathrm{U} / \mathrm{g}$ respectively.

There are many recent reports about purification and characterization of novel $\beta$-mannanases from microbial isolates [6], optimization of their $\mathrm{pH}-$ and thermal resistance [7] and engineering recombinant producers of these enzymes [8]. Taken together, this survey suggests conclusively that biodiversity of the non-studied $\beta$ mannanases remains broad and there is no commonly acknowledged biotechnological decision made relatively to requirements to $\beta$-mannanase. Therefore, our work 
pursued isolation of $\beta$-mannanases from epiphytic microbes associated with cereals and other plant species.

\section{Materials and methods}

\subsection{Growth media and growth conditions}

Liquid selective medium for isolation of $\beta$-mannanase product contained $1.5 \mathrm{~g} / \mathrm{L}$ of carob gum (LLC Uspekh, Russia), $1 \mathrm{~g} / \mathrm{L}$ of yeast extract, $1 \mathrm{~g} / \mathrm{L}$ of bactopeptone, $1 \mathrm{~g} / \mathrm{L} \mathrm{NH} \mathrm{Nl}_{4}, 1.4 \mathrm{~g} / \mathrm{L} \mathrm{KH}_{2} \mathrm{PO}_{4}, 0.2 \mathrm{~g} / \mathrm{L} \mathrm{MgCl}_{2}, 1 \% \mathrm{v} / \mathrm{v}$ of pipeline water as a source of microelements. The solid selective medium contained $9 \mathrm{~g} / \mathrm{L}$ M9 of minimal salts (Difco, USA), $1.0 \mathrm{~g} / \mathrm{L}$ of carob gum and $15 \mathrm{~g} / \mathrm{L}$ of bacto agar (Difco, USA).

The isolated $\beta$-mannanase producing strains were supported on a solid medium. The cultivation was carried out for $24-48 \mathrm{hrs}$. at $30^{\circ} \mathrm{C}$.

\subsection{Biological material for isolating $\beta$ - mannanase-producing microorganisms}

Plant material was collected in December 2020 in Shumyatino village (Kaluga region, Russia, GPS coordinates 54.993598, 36.336314). Fragments of dry stems with fruit remains were collected from plantain (Plantago major), wormwood (Artemisia vulgaris) and reed grass (Calamagrostis acutiflora). The plant material was kept in sterile plastic bags with zip-locks until delivered to the laboratory.

Specimens of the plant material ( $2 \mathrm{~g}$ each) were cut by sterile scissors and placed on $750 \mathrm{ml}$ Erlenmeyer flask containing $50 \mathrm{ml}$ of the selective medium with carob gum as a single source of carbon and energy. The flasks were then incubated in a thermostat without shaking for $24 \mathrm{hrs}$. at $30^{\circ} \mathrm{C}$.

$5 \mathrm{ml}$ aliquots of the cumulative cultures were spread by Drigalsky spatula at $90 \mathrm{~mm}$ on the Petri dishes with the solid selective medium and cultured for $72 \mathrm{hrs}$. at $30^{\circ} \mathrm{C}$.

The appeared colonies were smeared by microbiological loop at $90 \mathrm{~mm}$ Petri dishes with the solid selective medium of the above-mentioned composition and cultivated for $48 \mathrm{hrs}$. at $30^{\circ} \mathrm{C}$ for producing separate colonies. Three subsequent passages were carried by the same way out for obtaining pure cultures.

\subsection{Genomic DNA purification}

Pure cultures were inoculated to $3 \mathrm{ml}$ of the liquid full medium $(5 \mathrm{~g} / \mathrm{L}$ yeast extract, $10 \mathrm{~g} / \mathrm{L}$ bactopeptone, $10 \mathrm{~g} / \mathrm{L} \mathrm{NaCl}$ ) and incubated for $18 \mathrm{hrs}$. at $30^{\circ} \mathrm{C}$ with agitation at intensity $180 \mathrm{rpm}$.

The bacteria were precipitated by centrifuge for $1 \mathrm{~min}$ at $13,000 \mathrm{~g}$ and thoroughly re-suspended in $100 \mu \mathrm{l}$ $50 \mathrm{mM}$ EDTA, pH 8.0. $300 \mu \mathrm{l}$ lysis buffer (CTAB 1\%, $\beta$-mercaptoethanol $1 \%, \mathrm{NaCl} 4 \%$, Tris- $\mathrm{HCl} 50 \mathrm{mM}$, EDTA $50 \mathrm{mM}, \mathrm{pH} 8.0$ ) was added and mixed with the microbial suspension. $300 \mathrm{mg}$ glass beads with diameter $0.5-1.0 \mathrm{~mm}$ were added and the tubes were subjected to an intensive vortexation for $2 \mathrm{~min}$. The tubes were heated at $60^{\circ} \mathrm{C}$ for $30 \mathrm{~min}$. Equal volume of the chloroform was added, the tubes were subjected to an intensive vortexation and the phases were separated by centrifugation for $5 \mathrm{~min}$ at $13,000 \mathrm{~g}$. The upper (water) phase was collected and placed to an empty $1.5 \mathrm{ml}$ Eppendorf tube. The volume was determined and 3-fold excess of $96 \%$ ethanol was added. The tubes were kept at $-20^{\circ} \mathrm{C}$ for $10 \mathrm{~min}$ and centrifuged for $5 \mathrm{~min}$ at $13,000 \mathrm{~g}$. The pellet was dried and dissolved in $200 \mu \mathrm{l}$ deionized water. $200 \mu \mathrm{l}$ chloroform was added, the tubes was then subjected to vortexation and centrifuged for $5 \mathrm{~min}$ at $13,000 \mathrm{~g}$.

The upper (water) phase was collected and placed to an empty $1.5 \mathrm{ml}$ Eppendorf tube. The volume was determined and 2-fold excess of $96 \%$ ethanol and 1/10 v of saturated ammonium acetate were added. The tubes were centrifuged for $5 \mathrm{~min}$ at 13,000 $\mathrm{g}$ and the pellet was dried and solved in $50 \mu \mathrm{l}$ deionized water.

\subsection{S-rDNA amplification and sequencing}

Formerly described primers 8F AGAGTTTGATCCTGGCTCAG and 926R CCGYCAATTYMTTTRAGTTT for PCR amplification of 16S-rDNA gene fragment were used (Srivastava et al., 2008). Dream Taq DNA polymerase (Thermofisher Scientific, USA) was used in accordance with the manufacturer's instructions. $1 \mu \mathrm{l}$ DNA was used as a template per $30 \mu \mathrm{l}$ of the reaction mixture. PCR program was run at Thercyc MC-16 thermocycler (DNA-Technology, Russia) as following: preliminary denaturation $94^{\circ} \mathrm{C}-2 \mathrm{~min} ; 30$ cycles $\left(94^{\circ} \mathrm{C}-30 \mathrm{sec}\right.$, $45^{\circ} \mathrm{C}-45 \mathrm{sec}, 72^{\circ} \mathrm{C}-30 \mathrm{sec}$ ); completing the synthesis at $72^{\circ} \mathrm{C}$ for $2 \mathrm{~min}$.

The amplified $960 \mathrm{bp}$ long 16S-rDNA gene fragments were purified with a Silica Bead DNA Gel Extraction Kit (Thermofisher Scientific, USA) in accordance with the manufacturer's instructions. DNA sequencing was carried out by Eurogen Company (Russia) as a customer service. Both 8F and 926R primers were used for sequencing. The DNA sequences obtained by oncoming sequencing where merged and manually checked.

\subsection{Taxonomic assignment of the microbial isolates}

16S-rDNA sequences where uploaded to N-Blast service available on line (9). The most similar sequences were selected and used for reconstruction of a dichotomy tree.

\subsection{Cloning $\beta$-mannanase gene from Bacillus circulans and Bacillus subtilis}

Previously described primers $\quad$ S1 AAGTHCATGAYGCYACRGG- and S2 CCWGCATAYTCRTACATATGG (H means A, C, or $\mathrm{T}$; Y - C or T; R - A or G; W - A or T) corresponding to conserved regions of $\beta$-mannanases from bacteria belonging to genus Bacillus were used for PCR cloning 
of $\beta$-mannanases fragments from $B$. subtilis and B. circulans [10].

Previously described primers pEGF CGCGGATCCATGAGTACTTTTACTGTAGTACC CGC and pEG-R CCGCTCGAGTTAACTCAGAACGCTGCC

[11] specific to mannanase genes from Pantoea were used for cloning the fragments of the gene of interest from Pantoea ssp. siolate.

The PCR was carried out at Thercyc MC-16 thermocycler (DNA-Technology, Russia) under the following conditions: 30 cycles at $94^{\circ} \mathrm{C}$ in $40 \mathrm{sec}, 50^{\circ} \mathrm{C}$ in $30 \mathrm{sec}, 72^{\circ} \mathrm{C}-40 \mathrm{C}$.

\subsection{Enzymatic assay of $\beta$-mannanase activity}

The enzymatic activity of $\beta$-mannanase was assessed qualitatively on the Petri dishes with the selective medium of the abovementioned composition with the carob gum as described previously [12]. Briefly, the inoculated Petri dishes were cultured for 48 hrs., soaked in $1 \%(\mathrm{w} / \mathrm{v})$ Congo Red solution (LenReactiv, Russia) for $15 \mathrm{~min}$ and discolored with $1 \mathrm{M} \mathrm{NaCl}$ for $2 \mathrm{hrs}$.

\section{Results and discussions}

Searching for microbial isolates harboring $\beta$-mannanase genes was carried out during winter season when plant vegetation was impossible. The herbal species conserving fruit remains where chosen. Between these, the plantain (P. major), the wormwood (A. vulgaris) and the reed grass $(C$. acutiflora) were the most abundant in the chosen geographical location. For this reason, the dry stems with the fruit remains of these species putatively containing $\beta$-mannans were collected and used for isolation of the plant-associated microorganisms.

Using a massive $(50 \mathrm{ml})$ cumulative culture with subsequent plating of the germinated microorganisms onto selective solid medium, containing the carob gum (almost pure $\beta$-1-4-mannan) as the single source of the carbon and energy allowed to isolate the bacterial species exhibiting the properties listed in Table 1. The taxonomical classification of the appeared isolates was carried out on the basis of their 16S-rDNA sequencing.

The data in Table 1 supplemented with observation of the cultural properties of the isolates, allowing the following conclusions:

1. Each chosen plants species was colonized mostly with a single dominant epiphytic group of microorganisms exhibiting a $\beta$-mannanase activity although the plants grew in the same location.

2. Bacilli (B. subtilis and B. circulans) has been reported as sources of $\beta$-mannanase genes many times, whereas genus Pantoea (Bacteria; Proteobacteria; Gammaproteobacteria; Enterobacterales; Erwiniaceae; Pantoea) was appeared among potential producers of these enzymes only in a few works [13].
Table 1. Properties of bacterial species isolated from dry steams and fruit remains of herbal species using carob gum as a single source of the carbon and energy

\begin{tabular}{|c|c|c|c|c|}
\hline \multirow{2}{*}{$\begin{array}{l}\text { Sourc } \\
\text { e plant } \\
\text { specie } \\
\text { S }\end{array}$} & \multirow{2}{*}{$\begin{array}{l}\text { Morpholog } \\
\text { y of } \\
\text { microbial } \\
\text { colonies }\end{array}$} & \multicolumn{2}{|c|}{$\begin{array}{l}\text { The closest bacterial } \\
\text { isolate annotated in } \\
\text { NCBI GenBank }\end{array}$} & \multirow{2}{*}{$\begin{array}{l}\text { Taxonomi } \\
\text { cal } \\
\text { assignmen } \\
\mathrm{t} \text { on the } \\
\text { basis of } \\
16 \mathrm{~S}- \\
\text { rDNA } \\
\text { sequencin } \\
\mathrm{g}\end{array}$} \\
\hline & & $\begin{array}{l}\text { Accession } \\
\text { number and } \\
\text { description }\end{array}$ & $\begin{array}{l}\% \text { of } \\
16 S- \\
\text { rDNA } \\
\text { identi } \\
\text { ty }\end{array}$ & \\
\hline $\begin{array}{l}P . \\
\text { major }\end{array}$ & $\begin{array}{l}\text { Small } \\
\text { white } \\
\text { colonies } \\
\text { with small } \\
\text { prominence } \\
\text { S }\end{array}$ & $\begin{array}{l}\text { Bacillus } \\
\text { circulans } \text { strain } \\
\text { FDAARGOS } \\
\text { 783, CP053989 }\end{array}$ & 100 & $\begin{array}{l}\text { B. circula } \\
\text { ns }\end{array}$ \\
\hline $\begin{array}{l}\text { A. } \\
\text { vulgar } \\
\text { is }\end{array}$ & $\begin{array}{l}\text { Opaque } \\
\text { white } \\
\text { colonies } \\
\text { with long } \\
\text { coiling } \\
\text { prominence } \\
\text { s }\end{array}$ & $\begin{array}{l}\text { B. subtilis from } \\
\text { soil specimen } \\
\text { picked up from } \\
\text { a hot water } \\
\text { spring, } \\
\text { LC065158 }\end{array}$ & 98,5 & B. subtilis \\
\hline $\begin{array}{l}\text { C. } \\
\text { acutifl } \\
\text { ora }\end{array}$ & $\begin{array}{l}\text { Mucous } \\
\text { yellow/ora } \\
\text { nge } \\
\text { colonies }\end{array}$ & $\begin{array}{l}\text { Pantoea sp., } \\
\text { MK602498 }\end{array}$ & 98,1 & $\begin{array}{l}\text { Pantoea } \\
\text { sp. }\end{array}$ \\
\hline
\end{tabular}

The identification of taxonomic position of the isolated $\beta$-mannanase producers allowed using the formerly proposed primers for PCR cloning of the respective genes. This approach allowed obtaining $330 \mathrm{bp}$ fragment of $\beta$-mannanase genes from B. circulans and B. subtilis and $1000 \mathrm{bp}$ fragment from Pantoea sp.

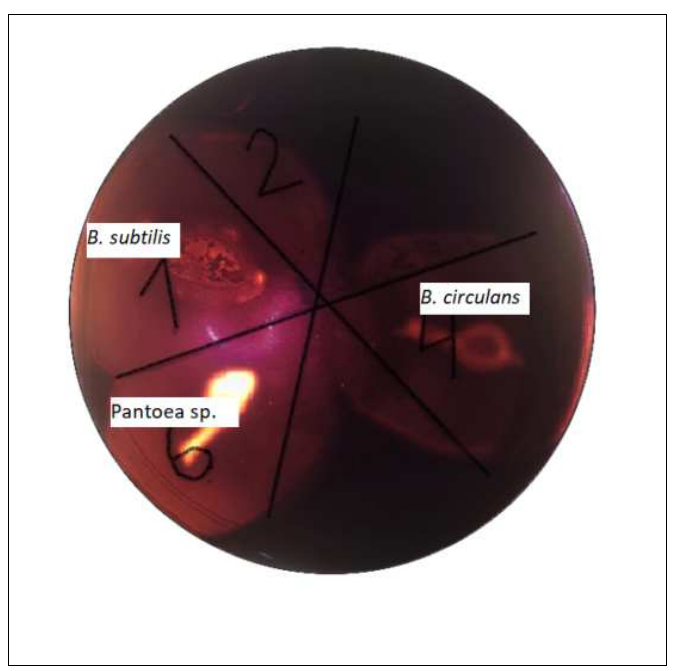

Fig. 1. Petri dish with the solid selective medium containing $1 \mathrm{~g} / \mathrm{L}$ carob gum as a single source of the carbon and energy with smeared culture of $B$. circulans, B. subtilis and Pantoea sp. after cultivation for $48 \mathrm{~h}$, staining with $1 \%$ Congo Red and distaining with $1 \mathrm{M} \mathrm{NaCl}$. The appeared halo demonstrates presence of the specific $\beta$-mannanase activity.

Testing $\beta$-mannanase activity in the obtained bacterial isolates (Fig. 1) led to the conclusion that the 
highest activity was found in Pantoea sp. found at C. acutiflora since this bacterial isolate grew well on a medium containing the carob gum as a single source of energy and exhibited the greatest halo in plate test for the mannanase activity with Congo Red.

B. circulans exhibited just a slow growth at the selective medium was, therefore just a low $\beta$-mannanase activity was suggested in it. B. subtilis grew well, however it exhibited a relatively poor substrate hydrolysis in the plate enzymatic test with Congo Red.

Polysaccharides containing linkages of the $\beta$ mannose are broadly found in the plant cell walls within the seeds (including the grain and the beans). These are mostly derivatives of $\beta$-1,4-mannan including pure $\beta$ mannan, glucomannan, galactomannan, and galactoglucomannan. These polymers are composed of a backbone constituted by chains of $\beta$-1,4-linked mannose residues and randomly decorated with $\alpha$-glucose and $\beta$ mannose side chains linked via $\alpha$-1,6-galactose residues [14]. Introducing $\beta$-mannan-degrading enzymes to the animal and poultry diet is beneficial for improving accessibility of its organic and mineral components. Mannooligosaccharides appearing as a result of $\beta$ mannan hydrolysis are beneficial as prebiotics and stimulators of the immunity. The exhaustive hydrolysis of the grain and bean $\beta$-mannan into monomers requires a combinations of several enzymes e.g. $\beta$-mannanase (EC 3.2.1.78), $\beta$-mannosidase (EC 3.2.1.25), $\beta$ glucosidase (EC 3.2.1.21), and $\alpha$-galactosidase (EC 3.2.1.22). $\beta$-mannanase can randomly hydrolyze the linkages $\beta$-D-1,4-mannopyranoside and has the highest significance for the plant $\beta$-mannan and overall diet assimilation [15].

$\beta$-Mannanases are broadly distributed in all kingdoms of the living organisms i.e. Eubacteria and Archae, filamentous and yeast-like fungi, plants. Structural properties of the amino acid sequences particularly catalytic center allow attribution of each known the $\beta$-mannanases to one of three $\mathrm{GH}$-families glycoside hydrolase: 5, 26, or 113 [16].

Bacterial $\beta$-mannanases usually have a moderate thermal stability $\left(\max .50-60^{\circ} \mathrm{C}\right)$ and $\mathrm{pH}$ optimum about 6.0 or higher. The most popular in practice $\beta$ mannanases from B. circulans, B. subtilis and other Bacilli belong to GH5 family. They exhibit the thermal stability up to $60^{\circ} \mathrm{C}$ and $\mathrm{pH}$ optimum in the range of 6.010.0. These enzymes are usually highly stable towards the thermal and chemical denaturation due to a presence of disulfide bonds.

$\beta$-Mannanases from Pantoe agglomerans and other gram-negative bacteria belong to $\mathrm{GH} 26$ family. They have thermal stability up to $50^{\circ} \mathrm{C}$ and $\mathrm{pH}$ optimum in range 6.0-6.5 [10]. Practically used recombinant $\beta$ mannanases often contain artificially introduced mutations beneath the active center e.g. Gly267Ser and His134Lys in the Man26P from P. agglomerans [10]. This allows improving the maximum catalysis rate up to 2.5-3.5 times versus the parental wild type enzyme.

The fungal $\beta$-mannanases may be members of both GH5 and GH26 families. They usually exhibit a higher catalytic rate but narrower substrate specificity versus their bacterial homologues. The fungal $\beta$-mannanases belonging to GH5 usually attack the native high molecular mass polysaccharide substrate and exhibit a low molar activity whereas members of GH26 usually responsible for the final degrading of the dextrin and oligosaccharides and work with a high rate.

Members of GH113 family are relatively rare found in the natural microbial isolates. Most of them were found in extremophile bacteria. Typically, the enzymes from this family are characterized with the higher thermal stability and broader substrate specificity than in other $\mathrm{GH}$ families but with a relatively low molar activity. They demonstrate a downward trend of activity toward galactomannan (guar and locust bean gum) with a high share of galactosyl. In contrast, their activity towards glucomannan from the konjac flour is high [17].

Most fungal $\beta$-mannanases from $\mathrm{GH} 5$ and $\mathrm{GH} 26$ families exhibit a higher activity on locust bean gum than on the konjac flour. The bacterial $\beta$-mannanases from both families have relatively looser structure of the active centers that facilitates recognition of different substrates.

\section{Conclusions}

The chosen methodology allows a rapid and laborefficient screening for $\beta$-mannanase producing strains and cloning of $\beta$-mannanase genes from them. Remains of the herbal stems and fruits were found to be an optimal source of the strains producing these type of the enzymes. The cloned genes are good for engineering recombinant producers of $\beta$-mannanase and direct testing the pure enzymes in the animal feeding experiments.

\section{References}

1. H. Ko, H.K. Kang, J. Moturi, S.L. Ingale, J. Kim (2021) J Anim Sci Technol., 63(1), 69-76

2. M. E. Jackson, D.W. Fodge, H. Y. Hsiao Poult Sci. 78(12), 1737-41 (1999)

3. H. Zangiabadi, M. Torki Trop Anim Health Prod. 42(6), 1209-17 (2010)

4. X. T. Zou, X. J. Qiao, Z. R. Xu. Poult Sci. 85(12), 2176-9 (2006)

5. L. Liu, H. Wen, Z. Rao, C. Zhu, M. Liu, L. Min, L. Fan Int J Biol Macromol.; 108, 376-382, (2018).

6. W. Liu, C. Ma, W. Liu, Y. Zheng, C.C. Chen, A. Liang, X. Luo, Z. Li, W. Ma, Y. Song, R.T. Guo, T. Zhang Int J Biol Macromol. 15 (182), 899-909, (2021)

7. B. Sadaqat, C. Sha, P. F. Rupani, H. Wang, W. Zuo, W. Shao Man. Front Bioeng Biotechnol. 16 (9), 637649, (2021) doi: 10.3389/fbioe. 2021.637649

8. Z. Liu, L. Cao, X. Fu, Q. Liang, H. Sun, H. Mou Microb Biotechnol. 4 (2021).

9. Standard Nucleotide BLAST, available at: https://blast.ncbi.nlm.nih.gov/Blast.cgi?PROGRA $\mathrm{M}=$ blastn\&PAGE_TYPE=BlastSearch\&LINK_L $\mathrm{OC}=$ blasthome 
10. S. Y. Wang, S. J. Wu, G. Thottappilly, R. Locy, \& N. Singh Journal of Bioscience and Bioengineering, 92, 59-66, (2001).

11. J. Wang, Q. Zhang, Z. Huang, Z. Liu $J$ Biotechnol.; 167(3), 350-6 (2013)

12. R. Peterson, J. Grinyer, J. Joss, A. Khan, H. Nevalainen, Journal of Microbiological Methods, 79 (3), 374-377, (2009)

13. J. Wang, Q. Zhang, Z. Huang, Z. Liu, J Biotechnol. 167(3), 350-6, (2013)

14. L.R. Moreira, E.X. Filho,. Appl Microbiol Biotechnol. 79, 165-178, (2008)

15. V. Lombard, R.H. Golaconda, E. Drula, P.M. Coutinho, B. Henrissat Nucleic Acids Res 42, D490 -D495, (2014)

16. W. Xia, H. Lu, M. Xia, Y. Cui, Y. Bai, L. Qian, P. Shi, H. Luo, B. Yao Appl Environ Microbiol. 82, $2718-2727$ (2016)

17. L.E. Tailford, V.M. Ducros, J.E. Flint, S.M. Roberts, C. Morland, D. L. Zechel, N. Smith, M. E. Bjørnvad, T.V. Borchert, K.S. Wilson, G. J. Davies, H. J. Gilbert Biochemistry 48, 7009 7018, (2009) 